$34-38$

\title{
Does lumbar decompression in overweight patients assist in postoperative weight loss?
}

\author{
Authors Paul A Anderson', Joseph R Dettori², Jeffrey T Hermsmeyer ${ }^{2}$ \\ Institutions ${ }^{\mathrm{I}}$ Department of Orthopedic Surgery and Rehabilitation, \\ University of Wisconsin, Madison, Wisconsin, USA \\ ${ }^{2}$ Spectrum Research, Inc., Tacoma Washington, USA
}

\section{ABSTRACT}

Study design: Systematic review.

Objective: To determine if there is a weight change in overweight patients following lumbar decompression with or without fusion for lumbar degenerative conditions.

Summary of background: Anecdotal evidence suggests obesity is a risk factor for recurrent disc herniation or adjacent segment degeneration after lumbar surgery. Weight loss after surgery therefore may be important to reduce risk of these problems. Theoretically, patients who recover may be able to increase exercise tolerance and therefore the possibility for weight loss is more likely. If spine patients are similar to knee arthroplasty then it is unlikely that substantial weight loss will occur after surgery. If true, then other patient centered programs need to be developed to help obese patient's loss weight after spine surgery.

Methods: A systematic review of the English language literature was undertaken for articles published between 1970 and March 2010. Electronic databases and reference lists of key articles were searched to identify studies evaluating weight change in overweight patients following lumbar decompression with or without fusion for lumbar degenerative conditions. Two independent reviewers assessed the strength of evidence using the GRADE criteria assessing quality, quantity, and consistency of results. Disagreements were resolved by consensus.

Results: We identified two articles meeting our inclusion criteria. Body weight change following lumbar surgery in overweight patients varied between the two included studies. One study reported $6 \%$ of patients lost weight 34 months following lumbar surgery, while $35 \%$ gained body weight. A second study reported $40 \%$ lost weight while $41 \%$ gained weight 20 months post surgery. Evidence from these two studies are limited due to small sample sizes, different definitions of overweight, and unequal lengths of follow up between the two studies.

Conclusion: There is no evidence that overweight patients consistently lose weight as a result of lumbar decompression with or without fusion. Two small studies suggest that an overweight patient undergoing lumbar surgery is as likely to gain weight as to lose weight following surgery.

This systematic review was funded by AOSpine. 


\section{STUDY RATIONALE AND CONTEXT}

Presence of obesity in patients facing spine surgery is seen as a risk factor due to the potential for increased perioperative complications. Further anecdotal evidence also suggests that higher rates of recurrent disc herniation and adjacent disc degeneration occur in patients with excessive weight. Therefore, patients with excessive body mass would ideally go through a preoperative weight reduction program prior to embarking on elective spine surgery. However, in practical reality this rarely happens due to common complaints of patients that effective weight reduction is not feasible due to pain and immobility resulting from their underlying spine condition. Commonly, plans are then made for patients to reduce weight after successful spine surgery through implementation of an exercise plan and other healthy life-style options. From anectodal impressions surgeons question the resolve of patients to actually embark on a long-term plan for weight reduction following spine surgery. The question therefore has been raised, are patients able to reduce excessive body weight after successful spine surgery?

\section{OBJECTIVES}

To determine if there is a weight change in overweight patients following lumbar decompression with or without fusion for lumbar degenerative conditions.

\begin{tabular}{|c|c|c|c|c|c|}
\hline $\begin{array}{l}\text { Author } \\
\text { (year) }\end{array}$ & $\begin{array}{l}\text { Study } \\
\text { design }\end{array}$ & $\begin{array}{l}\text { Study } \\
\text { population }\end{array}$ & $\begin{array}{l}\text { Surgery and diagnosis } \\
\text { percent }(\mathrm{n} / \mathrm{N})\end{array}$ & $\begin{array}{l}\text { Preoperative body weight/ } \\
\text { body mass index (BMI) } \\
\text { percent }(n / N)\end{array}$ & $\begin{array}{l}\text { Follow up } \\
\text { mean time, } \\
\text { percent }(n / N)\end{array}$ \\
\hline $\begin{array}{l}\text { Garcia } \\
(2008)\end{array}$ & $\begin{array}{l}\text { Retrospective } \\
\text { cohort }\end{array}$ & $\begin{array}{l}\mathrm{N}=63 \\
\text { male: } 59 \% \\
\text { age: mean } \\
53.4 \pm 8.1 \text { years } \\
(36-65)\end{array}$ & $\begin{array}{l}\text { Lumbar decompression with or without } \\
\text { fusion: } \\
\text { Stenosis: } 100(63 / 63)\end{array}$ & $\begin{array}{l}\text { Mean preoperative } \\
\text { Body weight: } 92.3 \pm 16.2 \mathrm{~kg} \\
\text { BMl: } 31.0 \pm 4.7 \mathrm{~kg} / \mathrm{m}^{2} \\
\text { Weight classification*: } \\
\text { Overweight: } 50.8(32 / 63) \\
\text { Obese: } 27.0(17 / 63) \\
\text { Morbidly obese: } 22.2(14 / 63)\end{array}$ & $\begin{array}{l}34.4 \text { months (24-51.3 } \\
\text { months), } 100(63 / 63)\end{array}$ \\
\hline $\begin{array}{l}\text { Vaidya } \\
\text { (2009) }\end{array}$ & $\begin{array}{l}\text { Retrospective } \\
\text { cohort }\end{array}$ & $\begin{array}{l}\mathrm{N}=63 \\
\text { male: } 40 \% \\
\text { age: mean } 53 \\
\text { years }(28-81)\end{array}$ & $\begin{array}{l}\text { Lumbar decompression and fusion: } \\
\text { Stenosis: } 50.8 \text { (32/63) } \\
\text { Degenerative disc disease: } 22.2 \text { (14/63) } \\
\text { Revision surgery for post laminectomy } \\
\text { instability: } 12.7(8 / 63) \\
\text { Spondylolisthesis: } 7.9 \text { (5/63) } \\
\text { Degenerative scoliosis: } 6.3(4 / 63)\end{array}$ & $\begin{array}{l}\text { Mean preoperative } \\
\text { Body weight: } 103.9 \mathrm{~kg}(68-158.7 \mathrm{~kg}) \\
\text { BMl: } 36.4 \mathrm{~kg} / \mathrm{m}^{2}\left(30-53 \mathrm{~kg} / \mathrm{m}^{2}\right) \\
\text { Weight classificationt: } \\
\text { Obese: } 50.8 \text { (32/63) } \\
\text { Morbidly obese: } 49.2(31 / 63)\end{array}$ & $\begin{array}{l}20.4 \text { months (14-37 } \\
\text { months), } 92(58 / 63)\end{array}$ \\
\hline
\end{tabular}

*Overweight $>25<30$; obese $\mathrm{BMI} \geq 30<35$; morbidly obese $\mathrm{BMI} \geq 35$

†Obese $\mathrm{BMI}>30<39$ and no comorbidity; morbidly obese, $\mathrm{BMI}>30<39$ with morbidity or BMI $>40$ and no comorbidity 


\section{MATERIALS AND METHODS}

Study design: Systematic review

\section{Sampling:}

- Search: PubMed, Cochrane collaboration database, and National Guideline Clearinghouse databases; bibliographies of key articles.

- Dates searched: 1970-March 2010.

\section{Inclusion criteria:}

(1) Degenerative lumbar disease

(2) Preoperative obesity

(3) Adults 18 years or older

\section{Exclusion criteria:}

(1) Trauma

(2) Tumor

(3) Infection

(4) Idiopathic scoliosis

Outcomes: Postoperative weight change, proportion of patients reflecting weight change.

Analysis: Descriptive statistics.

Details about methods can be found in the web appendix at www.aospine.org/ebsj

\section{RESULTS}

We identified two articles meeting our inclusion criteria (Figure 1). Both studies were retrospective cohort studies; one was graded a class of evidence II [1] and one was graded a class of evidence III [2]. Further details on the class of evidence determination can be found in the web appendix at www.aospine.org/ebsj. Characteristics of each study are outlined (Table 1).

\section{Weight change}

Body weight change following lumbar surgery in overweight patients varied between the two included studies [1, 2].

- Garcia et al [1] reported the proportion of patients experiencing weight change and mean weight change in three subgroups segregated by preoperative body mass index (BMI): "overweight" (BMI between 25 and 30), "obese" (BMI between 30 and 35), "morbidly obese" (BMI > 35). Weight change was defined as a change of $\pm 5 \%$ of preoperative body weight. Sixty-three patients had lumbar spinal stenosis and were treated by decompression with or without fusion. Only patients with a body mass index (BMI, $\mathrm{kg} / \mathrm{m}^{2}$ ) of greater than 25 were included. Follow up was assessed from 2 to 4.3 years. Those patients that remained within $5 \%$ of preoperative body weight were classified as having no change in body weight.

- Six percent of patients lost weight 34 months following lumbar surgery, while 35\% gained weight (Figure 2).

- The average gain in weight in all patients was $2.5 \mathrm{~kg}$, increasing from 92.3 to $94.8 \mathrm{~kg}$.

- Mean weight increased in overweight patients by, $1.8 \pm 4.7 \mathrm{~kg}$; obese patients, $2.0 \pm 3.7 \mathrm{~kg}$; and morbidly obese, $4.8 \pm 8.0 \mathrm{~kg}$ (Figure 3).

- The BMI increased significantly from 31.0 to $31.5 \mathrm{~kg} / \mathrm{m}^{2}$.

- Mean BMI increased in overweight patients by $0.6 \pm 1.5 \mathrm{~kg} / \mathrm{m}^{2}$; obese patients, $0.6 \pm 1.4 \mathrm{~kg} / \mathrm{m}^{2}$; and morbidly obese, $1.7 \pm 2.8 \mathrm{~kg} / \mathrm{m}^{2}$.

- Weight at the time of follow up was strongly correlated to preoperative weight and not to improvement in walking ability.

- Vaidya et al [2] retrospectively reviewed 58 of 63 patients with available postoperative weight record having BMI $>30$ who underwent lumbar decompression and fusion. Patients were subclassified in two groups: "obese", BMI greater than 30 and less than 40 with no comorbidity; and "morbidly obese" 
having BMI greater than 30 and less than 40 with comorbidities or having BMI $>40$ with no comorbidity. Assessment was performed at a mean 20.4 months with range (14-37 months). The authors did not define weight loss or weight gain.

- Forty percent of patients lost weight while $41 \%$ gained weight; (Figure 2).

- Weight loss among the obese was $27.6 \%$ while $48.3 \%$ gained weight. Among those that were morbidly obese $51.7 \%$ lost weight and $34.5 \%$ gained weight (Figure 4).

- A small increase in weight was observed; at baseline averaged 103.9 and at follow-up $104.1 \mathrm{~kg}$. Obese patients increased from 92.4 to $93.8 \mathrm{~kg}$. Morbidly obese patients increased from 114.3 to $115.7 \mathrm{~kg}$.

- Overall, no change occurred in BMI from baseline to follow-up. In obese patients BMI increased from 32.3 to 32.5 while morbidly obese patients had a decrease from 40.8 to $40.3 \mathrm{~kg} / \mathrm{mm}^{2}$.

\section{CLINICAL GUIDELINES}

No clinical guidelines were found addressing this question.

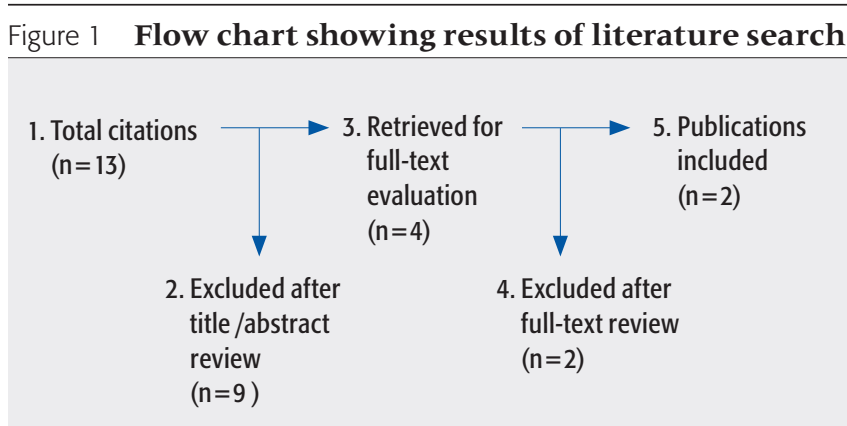

Figure 2 Proportion of overweight patients (\%) with weight change following lumbar decompression

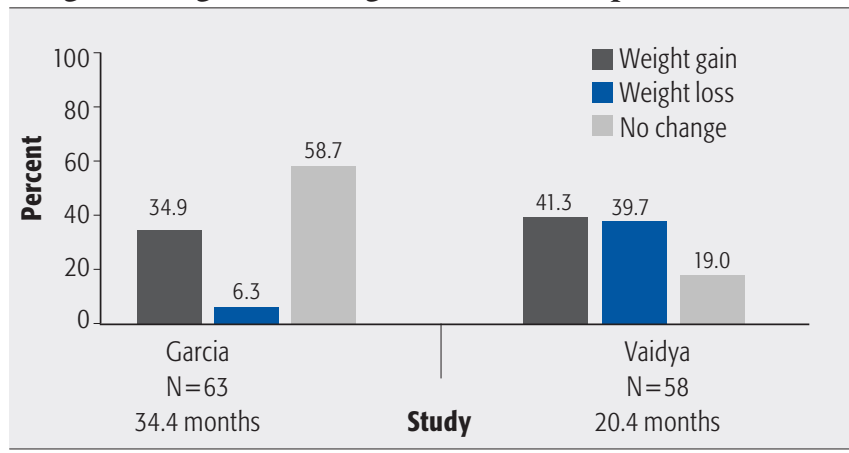

Figure 3 Mean weight change (kg) and standard deviation in patients with varying degrees of $\mathrm{BMI}^{*}$

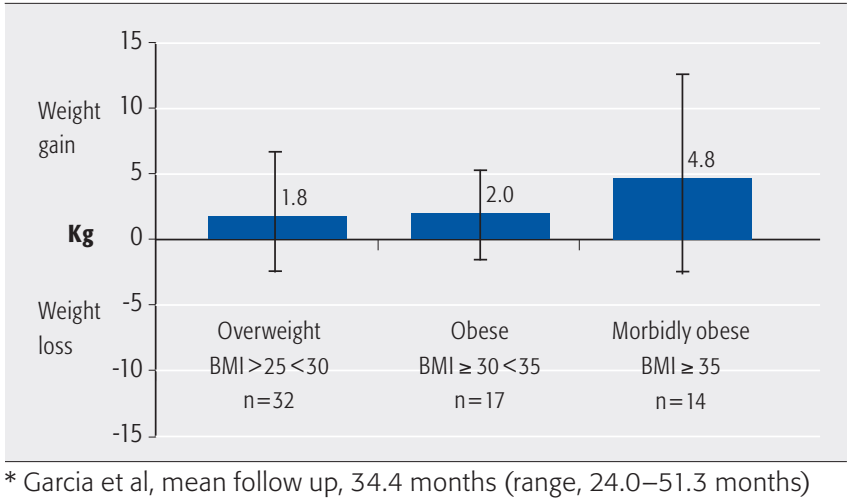

Figure 4 Proportion of obese and morbidly obese patients* with weight change following lumbar surgery $\dagger$

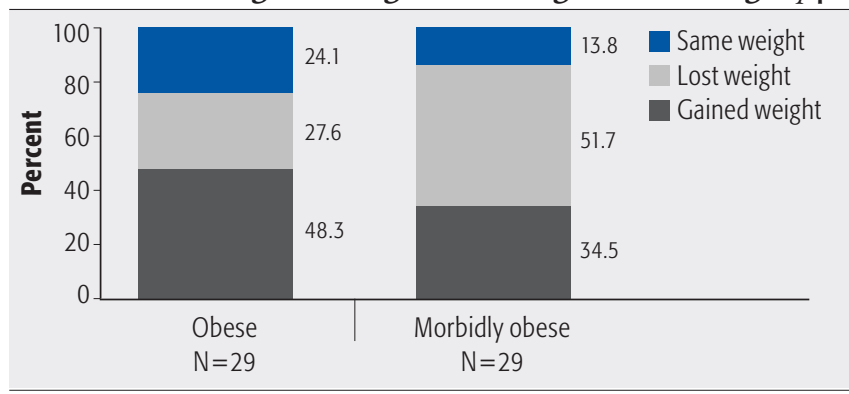

* Obese, BM > $30<39$ and no comorbidity, morbidly obese,

$\mathrm{BM}>30<39$ with comorbidity or $\mathrm{BM}>40$ and no comorbidity † Vaidya et al, mean follow up, 20.4 months (range, 14-37 months) 


\section{EVIDENCE SUMMARY}

\begin{tabular}{l|l|l|l}
\hline Weight loss in overweight patients following lumbar surgery. & \multicolumn{2}{c}{ Conclusions/comments } \\
\hline Outcomes & Strength of evidence & $\begin{array}{c}\text { - There is no evidence that overweight patients consistently lose weight as } \\
\text { a result of lumbar decompression with or without fusion. } \\
\text { Weight loss }\end{array}$ \\
\hline
\end{tabular}

\section{DISCUSSION}

- Despite its increasing prevalence in developed countries the association of obesity and elective lumbar spine surgery seems incompletely explored. This systematic review is limited due to the number of studies addressing the issue $(n=2)$. Furthermore, both studies had small sample sizes $(n=58, n=63)$. Only one study defined weight change. Each study used different definitions based on BMI to categorize degrees of obesity. Further differences included lengths of follow-up, variable surgical indications and procedure, and varying degrees of study quality.

- Hopes of discovering weight reduction in obese patients following lumbar spine surgery are disappointing. Based on these limited studies there is no evidence to suggest that patients despite lumbar spine surgery were consistently able to achieve weight loss. Instead, with the confinements of relatively shortterm follow-up, a small average weight gain averaging less than $2 \mathrm{~kg}$ was identified.
- These results are similar to the lack of weight loss reported after total knee replacement in obese patients.

- The relief of pain and improvement in function does not appear to be sufficient to induce weight change through increased active lifestyle in obese patients. This suggests that a different approach, which addresses the biopsychosocial aspects of disease, is required to achieve weight loss goals.

- Further research into the causes of lack of success with postoperative weight loss in obese patients undergoing spinal surgery seems warranted. More specifically, are patients with excessive weight following lumbar spine surgery actually able to lead more active lifestyles? If so, why did they not assume a more active lifestyle?

- Further research in exploring alternative approaches such as behavioral therapy and bariatric surgery need to be performed to address more sustained weight loss before and after spinal surgery. This may not only aid spinal health but the overall health of obese patients.

\section{REFERENCES}

1. Garcia RM, Messerschmitt PJ, Furey CG, et al (2008) Weight loss in overweight and obese patients following successful lumbar decompression. J Bone Joint Surg Am; 90:742-747.

2. Vaidya R, Carp J, Bartol S, et al (2009) Lumbar spine fusion in obese and morbidly obese patients. Spine; 34(5):495-500. 